\title{
NUTRIENT INTAKE OF WEST AFRICAN DWARF GOATS FED DIETARY MODELS OF ENSILED CASSAVA PEEL MEAL FORTIFIED WITH CALCIUM-PHOSPHORUS SALT
}

\author{
Ajagbe AD*, Aribido So \\ Department of Animal Production, Kogi State University, Anyigba, Nigeria, Email: adekunleajagbe1@gmail.com
}

Received: 07 October 2021, Revised and Accepted: 20 October 2021

\section{ABSTRACT}

Objective: This study was conducted to determine nutrient intake of growing West African Dwarf goats fed different dietary models of ensiled cassava peel meal fortified with Calcium-Phosphorus salt mix.

Methods: Twenty (20) growing West African Dwarf female goats aged 6-8 months with an initial weight of $8.2 \mathrm{~kg} \pm 0.25 \mathrm{were}$ used for the study. They were randomly allotted to four dietary treatments with five goats per treatment in a completely randomized design. The dietary treatments were Diet 1 (block), Diet 2 (crunchy), Diet 3 (pellet), and Diet 4 (mash).

Results: Results obtained indicated that dry matter intake ranged from $466.18 \mathrm{~g} / \mathrm{d}$ to $575.53 \mathrm{~g} / \mathrm{day}$ with significantly (p<0.05) higher value in pellet model while crude protein intake was higher in mash model than other treatments. Ether extract and crude fiber intake values were higher $40.13 \mathrm{~g} /$ day and $148.08 \mathrm{~g} /$ day in pellet feed model. Ash intake ranged from $61.32 \mathrm{~g} /$ day to $95.86 \mathrm{~g} /$ day. Block and crunchy models had significantly (p<0.05) higher value for ash intake while values obtained for nitrogen-free extract intake was also higher $(\mathrm{p}<0.05)$ in pellet model $22.62 \mathrm{~g} / \mathrm{day}$ than other models. Values of fiber fractions intake obtained were significantly $(\mathrm{p}<0.05)$ influenced by dietary models with higher values for neutral detergent fiber, acid detergent fiber and hemicellulose in mash while acid detergent lignin was significantly $(\mathrm{p}<0.05)$ for pellet model.

Conclusion: It can be concluded that supplementing goat diets with different dietary models of ensiled cassava peel meal fortified with Calcium- Phosphorus salt mix can boost intake of goats for better productive performance and productivity.

Keywords: Nutrient, ensiled; WAD, models, cassava peel, calcium- phosphorus, salts.

(C) 2021 The Authors. Published by Innovare Academic Sciences Pvt Ltd. This is an open access article under the CC BY license (http://creativecommons. org/licenses/by/4.0/) DOI: http://dx.doi.org/10.22159/ijags.2021v9i6.40703. Journal homepage: https://innovareacademics.in/journals/index.php/ijags

\section{INTRODUCTION}

Inadequate feed supply that confers adequate nutrients in ruminant nutrition has been a major challenge to goat producers and researchers. Small ruminants suffer scarcity of feed supply and pasture quality especially during the dry season when the nutritive value of natural vegetation declines [1], [2] stated that feed shortage is a major constraint in livestock production. Native rangelands produce the cheapest source of nutrients for goats but greater part of the grassland does not supply sufficient nutrients to livestock for greater productivity [3]. As a result, this leads to low productive performance of goats in terms of intake, digestibility and weight gain. However, in order to address problems of feed shortage, animals are often made to subsist on household wastes and crop residues [4] as supplements to their grazing activities on the available pastures. Such crop residue includes cassava peel, as an important by-product available from the processing of cassava (Manihot esculentus) root for food uses, starch, ethanol, and other by- products. Cassava has been used in feeding various classes of livestock [5]. However, during the dry season, the native rangeland and crop residues available for ruminants after crop harvest are usually fibrous and devoid of most essential nutrients including protein, energy, minerals and vitamins which are required for increased rumen microbial fermentation and improved performance of the host animal [6]. This often results in weight loss, low birth weight, lowered resistance to disease and reduced animal performance [7]. In response to these challenges, the recent approach has been to supplement livestock diets with protein-rich ingredients and fortification with minerals with further transformation into different dietary models to address the challenges associated with reduced growth performance and other productive parameters. This study was, therefore, conducted to investigate nutrient intake of West African Dwarf goats fed different dietary models of ensiled cassava peel meal fortified with Calciumosphorus salt mix.

\section{METHODS}

\section{Experimental site}

This experiment was conducted at the Sheep and Goat Unit of the Teaching and Research Farm of Kogi State University, Anyigba in accordance with the Institution's animal ethical committee guideline. Kogi State University, Anyigba lies on latitude $7^{0} 15^{1}$ and $7^{0} 29^{1}$ North of the equator and longitude $7^{0} 11^{1}$ and $7^{0} 32^{1}$ East of the Greenwich Meridian. The experimental location falls within the derived savannah zone of Nigeria, lying in the warm humid climate of the middle belt zone of Nigeria with a clear dry and raining season in May to October and October to March, respectively. The temperature ranges from 25 to $30^{\circ} \mathrm{C}$ with the highest in March and April [8].

\section{Experimental feed and treatment}

Fresh cassava peel, free from stumps were collected and grated before being subjected to hydraulic press for dewatering. The dewatered peels were then pulverized and sieved to obtain the coarse mash, which was then sun-dried for 2-5 days before being loaded into bags for feeding animals [9]. Four kilograms (4 kg) of urea fertilizer was dissolved in $100 \mathrm{~L}$ of water and then used to treat $100 \mathrm{~kg}$ of cassava peels by spraying. The product was then pressed together to eliminate air while in the 
container. The product in the container was then covered with plastic sheet and ensiled for 21 days before being used for diet formulation [10]. After then, it was air dried for 1-3 days. The feed was fortified with trona and single superphosphate (Calcium-Phosphorus salt mix) before being transformed into different forms viz: block, crunchy, pellet and mash as dietary treatments(Table 1). A mash form is coarse in nature. The crunchy form was made by mixing the feed ingredients with water and cement as a binding agent, moulded on a flat surface structure then air dried for about 3-4 days. The block form was obtained by mixing the feed ingredients with water and cement as a binding agent and then placed in container (mould) in a well-ventilated environment for about 4-7 days to assume the shape of the container [1]. The pellet form was obtained by mixing all the ingredients then transformed into pellets using pelleting machine.

\section{Experimental animals and management}

Twenty (20) growing West African Dwarf female goats aged 6-8 months with an initial weight of $8.2 \mathrm{~kg} \pm 0.25$ were used for the study. The goats were bought from Anyigba market, Kogi State and were allowed 14-days adaptation before the start of the feeding trial. All the animals were subjected to recommend vaccination procedures including treatment against endo and ectoparasites after which the animals were randomly assigned to four experimental dietary forms derived from urea treated cassava peel meal fortified with trona and single superphosphate viz block, crunchy, pellet and mash forms in a completely randomized design. The goats were allowed 6-7 h grazing daily before concentrate supplements were offered in their individual pens at $5 \%$ body weight for 60 days. Data on feed intake were collected throughout the experimental period. Nutrient intake was determined as the product of feed intake and percentage nutrient composition.

\section{Chemical analysis}

Samples of experimental diets were collected and analyzed for nutrient composition using methods of the Association of Official Analytical Chemist [11]. Feed samples were separately evaluated for fibre components in accordance with the methods of [12].

\section{Statistical analysis}

All data collected were subjected to Analysis of Variance. Means were separated by using Least Significant Difference according to the procedure of analysis in SPSS version 19.

\section{RESULTS}

\section{Nutrient composition of experimental diets}

Nutrient composition of supplementary diet is presented in Table 2 . Dry matter content of the experimental diet ranged between $85.01 \%$ and $86.50 \%$ with block having slightly higher value than other models. Organic matter ranged from $67.95 \%$ to $75.98 \%$ with pellet having higher value. Crude protein content comparably varied from $17.06 \%$ to $17.54 \%$ with crunchy model having lowest value but pellet having the highest value. Crude fiber content ranged from $20.59 \%$ to $22.08 \%$. Higher value of crude fiber was observed in block model $22.08 \%$ than other diets. Ether extract showed higher value in pellet diet $5.93 \%$ than other dietary models. Ash content varied between $9.06 \%$ and $18.55 \%$. The higher value for ash content was observed in block $18.55 \%$ and crunchy model (15.94\%) while pellet had the lowest value $9.06 \%$. Nitrogen free extract was higher in mash $44.85 \%$ but lower in block $23.56 \%$. Neutral detergent fiber ranged from $39.50 \%$ to $64.50 \%$. Higher value of $64.50 \%$ was observed in mash than other models. Acid detergent fiber was also higher in mash $88.67 \%$ whereas acid detergent lignin showed the highest value in block form 23.08. Hemicellulose had the lowest value $17.52 \%$ in block, but higher value of $24.17 \%$ was obtained in mash.

Nutrient intake of West African dwarf goats fed dietary models derived from urea treated cassava peels fortified with Ca-P Salt Mix

The result of nutrient intake is presented in Table 3 . The dry matter intake ranged from $466.18 \mathrm{~g} / \mathrm{d}$ to $575.53 \mathrm{~g} / \mathrm{d}$ with pellet model having

\section{Table 1: Gross composition of different dietary models (\%)}

\begin{tabular}{lllll}
\hline Ingredients & Block & Crunchy & Pellet & Mash \\
\hline Urea treated cassava peel & 92 & 92 & 95 & 95 \\
Cement & 3 & 3 & - & - \\
Trona & 4 & 4 & 4 & 4 \\
Single superphosphate & 1 & 1 & 1 & 1 \\
Total & 100 & 100 & 100 & 100 \\
\hline
\end{tabular}

Table 2: Nutrient composition of dietary models derived from urea-treated cassava peels fortified with Ca- P salts (\%)

\begin{tabular}{lllll}
\hline Nutrients (\%) & Block & Crunchy & Pellet & Mash \\
\hline Dry matter & 86.50 & 85.97 & 85.04 & 85.01 \\
Organic matter & 67.95 & 70.03 & 75.98 & 74.40 \\
Crude protein & 17.17 & 17.06 & 17.54 & 17.09 \\
Crude fibre & 22.08 & 20.59 & 21.88 & 21.67 \\
Ether extract & 5.14 & 4.94 & 5.93 & 5.78 \\
Ash & 18.55 & 15.94 & 9.06 & 10.61 \\
NFE & 28.56 & 32.41 & 35.19 & 49.85 \\
NDF & 32.50 & 39.50 & 47.50 & 64.50 \\
ADF & 50.02 & 59.49 & 69.47 & 88.67 \\
Hemicellulose & 17.52 & 19.99 & 21.97 & 24.17 \\
ADL & 23.08 & 15.79 & 19.09 & 18.01 \\
\hline
\end{tabular}

NFE: Nitrogen free extract, NDF: Neutral detergent fibre, ADF: Acid detergent fibre, ADL: Acid detergent Lignin

Table 3: Nutrient intake of WAD goats fed dietary models derived from urea treated cassava peels fortified with Ca-P salt mix (g/day)

\begin{tabular}{llllll}
\hline Parameters & Block & Crunchy & Pellet & Mash & SEM \\
\hline Dry matter & $446.18^{\mathrm{d}}$ & $506.33^{\mathrm{c}}$ & $575.53^{\mathrm{a}}$ & $547.62^{\mathrm{b}}$ & 2.47 \\
Organic matter & $350.49^{\mathrm{d}}$ & $413.42^{\mathrm{c}}$ & $514.21^{\mathrm{a}}$ & $504.18^{\mathrm{b}}$ & 2.45 \\
Crude protein & $88.56^{\mathrm{c}}$ & $100.71^{\mathrm{a}}$ & $98.40^{\mathrm{ab}}$ & $102.26^{\mathrm{a}}$ & 1.59 \\
Ether extract & $26.51^{\mathrm{c}}$ & $29.16^{\mathrm{b}}$ & $40.13^{\mathrm{a}}$ & $39.17^{\mathrm{a}}$ & 0.86 \\
Crude fibre & $113.89^{\mathrm{c}}$ & $121.55^{\mathrm{b}}$ & $148.08^{\mathrm{a}}$ & $146.85^{\mathrm{a}}$ & 5.19 \\
Ash & $95.68^{\mathrm{a}}$ & $94.10^{\mathrm{a}}$ & $61.32^{\mathrm{c}}$ & $71.90^{\mathrm{b}}$ & 0.49 \\
NFE & $121.52^{\mathrm{d}}$ & $161.81^{\mathrm{c}}$ & $224.62^{\mathrm{a}}$ & $187.51^{\mathrm{b}}$ & 10.32 \\
NDF & $270.08^{\mathrm{c}}$ & $233.18^{\mathrm{d}}$ & $321.46^{\mathrm{b}}$ & $487.51^{\mathrm{a}}$ & 12.28 \\
ADF & $309.59^{\mathrm{d}}$ & $351.19^{\mathrm{c}}$ & $470.15^{\mathrm{b}}$ & $600.88^{\mathrm{a}}$ & 24.13 \\
Hemicellulose & $90.37^{\mathrm{d}}$ & $118.01^{\mathrm{c}}$ & $148.69^{\mathrm{b}}$ & $168.79^{\mathrm{a}}$ & 5.20 \\
ADL & $119.05^{\mathrm{c}}$ & $93.21^{\mathrm{d}}$ & $129.20^{\mathrm{a}}$ & $122.05^{\mathrm{b}}$ & 2.05 \\
\hline
\end{tabular}

$\mathrm{a}, \mathrm{b}, \mathrm{c}, \mathrm{d}$ Means in the row with different superscripts are significantly different ( $\mathrm{p}<0.05)$, SEM: Standard error of the mean, NFE: Nitrogen free extract,

NDF: Neutral detergent fiber, ADF: Acid detergent fibre, ADL: Acid detergent Lignin

significant $(p<0.05)$ higher value. Organic matter intake followed similar trend. Crude protein intake varied from $100.71 \mathrm{~g} / \mathrm{d}$ to $88.56 \mathrm{~g} / \mathrm{d}$ significantly $(\mathrm{p}<0.05)$ higher value $102.26 \mathrm{~g}$ was observed in mash feed model than other treatments. Values of ether extract and crude fibre intake were significantly $(\mathrm{p}<0.05)$ higher $40.13 \mathrm{~g} / \mathrm{d}$ and $148.08 \mathrm{~g} / \mathrm{d}$ in pellet feed model. Ash intake ranged from $61.32 \mathrm{~g} / \mathrm{d}$ to $95.68 \mathrm{~g} / \mathrm{d}$. Block and crunchy models had significant $(\mathrm{p}<0.05)$ higher value for ash intake. The value of nitrogen free extract intake was significantly $(\mathrm{p}<0.05)$ higher in pellet model $224.62 \mathrm{~g}$ than other treatments. Fiber fractions intake (neutral detergent fibre, acid detergent fibre, acid detergent lignin and hemicellulose) were significantly influenced by dietary models. Neutral detergent fibre significantly $(\mathrm{p}<0.05)$ ranged from $487.51 \mathrm{~g} / \mathrm{d}$ to $270.08 \mathrm{~g} / \mathrm{d}$. Its intake was significantly affected by enrichment and fortification of cassava peel meal with higher value in mash model $487.51 \mathrm{~g} / \mathrm{d}$. Acid detergent lignin significantly $(\mathrm{p}<0.05)$ varied between $600.88 \mathrm{~g} / \mathrm{d}$ and $309.59 \mathrm{~g} / \mathrm{d}$ with mash model having higher value $600.88 \mathrm{~g} / \mathrm{d}$ than other dietary treatments. Acid detergent lignin intake was higher in pellet form $129.20 \mathrm{~g} / \mathrm{d}$ while significant $(\mathrm{p}<0.05)$ higher value of hemicellulose intake was observed to be higher in mash model $163.79 \mathrm{~g} / \mathrm{d}$ than other dietary models. 


\section{DISCUSSION}

Dry matter content of the dietary models across the treatments ranged between $85.01 \%$ and $86.50 \%$. This value range is comparable to $87.52 \%$ reported by Ukanwoko and Ibeawuchi [13] for cassava based diets fed to WAD goats. But lower than $90.30-91.84 \%$ reported by Guimaraes et al. [14] for diets containing cassava peels fed to goats. The values of organic matter content observed is comparable to the values obtained by Guimaraes et al. [14] but lower than $92.52 \%$ to $93.70 \%$ reported by Uza et al. [15] for urea treated cassava peels offered WAD goats. Crude protein content obtained was higher than $15.29 \%-15.75 \%$ reported by Guimaraes et al. [14].

The values observed indicated that pellet model had higher crude protein. More so, all the diets seemed to be isoproteic due to similar values obtained. Crude fiber content obtained was higher than $16.60 \%$ reported by Ukanwoko and Ibeawuchi [13]. The values of ether extract are comparable across the dietary treatment but slightly lower than $6.04 \%$ reported by Kalio et al. [16] for urea treated cassava peel fed to WAD goat. Ash content was higher in treatment group with block form than other diets forms. The high value of ash content in block form followed by crunchy might be attributed to cement powder used as binder in block form. This is applicable to crunchy form also. The inclusion of trona and superphosphate minerals buffers might as well contributed to increased ash content. This is in harmony with a report of Hoffman and Tayson [17] who opined that mineral buffer supplementation may contribute to high dietary ash content. Nitrogen free extract was higher in pellet model treatment group. The value of nitrogen-free extract obtained in this study was lower than $62.67 \%$ reported by Aye [18] for cassava peel supplemented with Moringa oleifera, Gmelina arborea and Tithonia diversifolia based multinutrient block. The value was also higher than $32.36 \%$ reported by Kalio et al. [16] for cassava peels supplemented with $\mathrm{N}$ sources. Variations might be due to urea treatment of cassava peel used in this study. Urea treatment might have interfered with the protective effect of cellulosic material of the feed thereby making it more digestible. Neutral detergent fibre and acid detergent fibre were higher than $30.06 \%$ and $16.00 \%$ reported by Kalio et al. [16] respectively. Acid detergent lignin content was higher than $7.94-10.97 \%$ reported by Guimaraes et al. [14]. The variation in the results obtained might be attributed to stage of maturity of cassava, processing methods adopted in obtaining the cassava peels used in the different experiments, soil condition and environmental factors. Dry matter intake and organic matter intake were higher in pellet model than other dietary groups. Lower intake in block and crunchy may be attributed to the nature of the diet. The higher dry matter and organic matter intake obtained may be due to the pelletized form of the diet which enabled ease of picking and mastication of feed. This agrees with the findings of [19] who reported that grinding and pelleting agro-by product help in increasing the palatability of the feed which correlates to better intake. The result of dry matter intake obtained in this study was higher than $426.71 \mathrm{~g} /$ day- $478.08 \mathrm{~g} /$ day reported by Faria [20] on a research carried out involving different methods of processing cassava peel. The values obtained for dry matter and organic matter intake is in contrast with [21] who reported that organic matter and dry matter intake were not affected by inclusion of cassava peel supplements. Crude protein intake ranged between $88.56 \mathrm{~g} /$ day and $102.26 \mathrm{~g} /$ day.

The values of crude protein intake were lower than $127.31 \mathrm{~g} /$ day, $120.14 \mathrm{~g} /$ day and $118.30 \mathrm{~g} /$ day reported by Menezes et al. [22] for varying levels of cassava peel fed to ruminants. The crude protein intake was influenced by dietary supplements in this study and is in contrast to [14] who obtained $132 \mathrm{~g}$ /day in their study on performance of lambs fed diets containing cassava peels. Ether extract and crude fibre intake were higher in dietary groups fed pellet diet. Increase palatability and digestibility of pellet rations together with efficient utilization of absorbed nitrogen maybe responsible for increased intake. Ash intake was influenced by dietary feed models whereby block diet group had the highest value $95.68 \%$ this might be attributed to cement used as a binder in block dietary group. This is supportive with the higher value
$94.00 \%$ of ash intake obtained in crunchy diet wherewith cement was also used as a binder. Hoffman and Tayson [17] reported that mineral inclusion may contribute to high ash content because cement contains calcium carbonate as one of the major components.

Nitrogen free extract intake was higher in pellet diet than other treatments. Result obtained agrees with [23] that higher intake of nitrogen free extract was observed with pelletized diet. Intake of neutral detergent fibre, acid detergent fibre was high in mash model than other dietary groups while acid detergent lignin was higher in pellet group. The higher intake of fibre component obtained in this study is a proof of better degradability of the diet in the rumen of the animals which favoured better rumen environment. The results of fibre fractions intake obtained in this study agree with [24] who reported that neutral detergent intake, acid detergent fibre were influenced by levels of cassava peels in pellet model.

\section{CONCLUSION}

Based on the results obtained from this study, it was concluded that supplementing diets of grazing West African Dwarf goats with ureatreated cassava peels fortified with Calcium - Phosphorus mineral mix (Trona and Single superphosphate fertilizer) in different dietary models can boost nutrient intake of goats which invariably results to better productive performance of the animals.

\section{ACKNOWLEDGMENT}

The researcher acknowledges the efforts of all technical staff of Livestock Teaching and Research Farm of Kogi State University, Anyigba.

\section{REFERENCES}

1. Aye PA. Production of Multinutrient Blocks for Ruminants and Alcohol from the Waste Products of Leucaena leucocephala and Gliricidia sepium Leaves Using Local Technologies. PhD Thesis. Akure, Nigeria: Federal University of Technology; 2007. p. 45.

2. Ahamefule FO, Elendu C. Intake and digestibility of West African Dwarf bucks fed cassava leaf-maize offal based diets. J Anim Vet Adv 2010;9:535-9.

3. Ndlovu LR. Complementarity of forages in ruminant digestion: Theoretical considerations. In: Stares JE, Said AN, Ketagile JA, editors. The Complementality o Fèed Resources in Animal Production in Africa. Botswana: Proceedings of the Joint Feed Resources Networks Workshop Held in Gaborone, Botswana; 1992. p. 17-23.

4. Odeyinka SM. Feeding behaviour and diet selection by West African Dwarf Goats (Short Communication). Arch Tier Dummers 2000;43: 57-61.

5. Akinfala EO, Tewe OO. Supplemental effects of feed additives on the utilization of whole cassava plant by growing pigs in the tropics. Lives Res Rurl Dev 2010;16:20-4.

6. Osuji PO, Fernandez-Rivera S, Odenyo A. Improving the utilization and protein supply in animal fed poor-quality roughages: ILRI Nutrition Research and Plans. In: Wallace RJ, Lahlou-Kassi A, editors. Rumen Ecology Research Planning (EDS). Addis Ababa: Rumen Ecology Research Planning. Proceedings of a Workshop; 1995. p. 1-2.

7. Onwuka CF, Akinsoyinu AO, Tewe OO. Feed value of some Nigerian browse species: Chemical composition and in vitro digestibility of leaves. J Est Afr Agric 1989;54:157-63.

8. Ifatimehin OO, Musa SD, Adeyemi JO. Analysis of the changing land use and its impact on the environment of Anyigba Town, Nigeria. J Sust Dev Afr 2006;10:45-50.

9. Ajagbe AD, Oyewole BO, Aribido SO, Sunday PA. Performance of West African dwarf goats fed cassava peels treated with nitrogen sources GSC. Biol Pharm Sci 2020;10:9-12.

10. Puck B, Arno M, Jolianne R. Dairy cattle management. Agrodok Series $2004 ; 14: 23$

11. Association of Official Analytical Chemist. Official Methods of Analysis. $18^{\text {th }}$ ed. Arlington, VA: Association of Official Analytical Chemist; 2005. p. 806-42.

12. Van Soest PJ, Robertson JB. Dietary fibre estimation in concentrates feedstuffs. J Anml Sci 1985;45:254.

13. Ukanwoko AI. Ibeawuchi JA. Evaluation of cassava leaf meal based diet for milk production by the West African Dwarf goats in south 
eastern Nigeria. J Agric Vet Sci 2014;7:27-30

14. Guimaraes GS, Silva da FF, da Silva LL, Galvao LM, dos Santos LM, Alencar AM. Intake, digestibility and performance of lambs fed with diets containing cassava peels. Sci Agrotech 2014;38:295-302.

15. Uza DV, Barde RE, Ayoade JA. The effects of urea treated cassava peels as supplements to West African Dwarf goats grazing natural pasture. Nig Vet J 2005;26:1-5.

16. Kalio GA, Ayuk AA, Agwunobi LN. Performance of West African Dwarf Goats fed N-treated source and forage supplemented cassava peel in humid Cross Rivers State, Nigeria. Am J Exp Agric 2014;4:629-38.

17. Hoffman PC, Tayson D. How much ash are you feeding your cow. Hrds Dairymen 2005;149:659.

18. Aye PA. Growth rate, physiological parameters, haematological indices and nutrient utilization in West African Dwarf sheep fed Cajanus cajanbased feed blocks as supplements. Int J Agric Innov Res 2015;3:1261-6.

19. Reddy SK, Reddy MR. Utilization of wheat straw/berseem hay and poultry droppings in the development of complete feeds for crossbred bulls. Indian J Anml S 1989;59:981-5.

20. Faria BP. Processamento da casca de mandioca na alimentação de ovinos: Desempenho, características de carcaça, morfologia ruminal eficiência econômica. Rev Bras Zootech 2011;40:2929-37.

21. Conceicao OW. Valor Nutritivo de dietas contendo raspa integra da mandiocra para ovinos confinados. Acta Sci Anim Sci 2009:31:397-402.

22. Menezes MP, Macedo FA, Siqueira ER, Martins EN. Substituição do milho pela casca de mandioca (Manihot esculenta Crantz) em rações completas para caprinos: Consumo, digestibilidade de nutrientes e ganho de peso. Rev Bras Zootec 2004;33:729-37.

23. Rashid MA, Khan MJ, Khandoker MA, Monir MM. Feeding of different forms of ration including compound pellet and performance of growing black Bengal goats. Agric Vet Sci 2016;9:1-8.

24. Oduguwa BO, Amole TA, Okwelum N, Oni AO, Toviesi PD, Oderinwale OA, et al. Performance, storability and microbiological assay of pelletized and un-pelletized cassava based diets fed to Muturu calves. Afr J Agric Res 2013;8:2750-6. 